\title{
SOME LEGAL ASPECTS OF COMPENSATION FOR NATIONALIZED ASSETS
}

\author{
Mary Bell Carrns*
}

I

It may seem axiomatic to an English lawyer to say that any expropriation of property by the state must inevitably give rise to the question of compensation for those persons whose assets and interests have been affected, because the principle of compensation for assets compulsorily transferred from private to public ownership has long been established in English law. To most continental lawyers, ${ }^{1}$ however, such a principle is unrecognized, while to others, such as those of the United States of America, it is in practice, if not in theory, almost unknown since nationalization of industry is a tenet which has but little practical influence in that country. ${ }^{2}$

The subject of compensation for assets which have been compulsorily acquired by the state ${ }^{3}$ is a matter of great practical importance in England at the present time on account of the nationalization of different types of industry in recent years. To onlookers in other countries, it is also a matter of some interest, not only because of the basic principle of compensation itself, but also on account of the terms of the compensation, the methods of its assessment, and its value as compared with that of the transferred assets.

Before considering the details of the compensation awarded to the owners of those industries which have recently been compulsorily acquired by the state, some general observations must first be made upon the legal rules which underlie the principle of compensation for the expropriation of property as it is applied in

* LL.B. I937, LL.M. 1947, University of Bristol; Ph.D. (Faculty of Law) I950, London School of Economics and Political Science, University of London; of the Middle Temple and Western Circuit, Barrister-at-Law; a member of the Bristol City Council, x941-I944.

${ }^{1}$ See the cases cited in C. M. Schmitrhoff, A Textrook of the English Conflict on Laws (2d cd. 1948), at 55, 56, e.g., a decree of confiscation of June, I918, by the Sovict Government gave no right of compensation to those persons whose property was expropriated: Luther v. Sagor, [192X] 3 K. B. 532; a similar decree of the Spanish Government requisitioning ships registered in Bilboa: Campania Naviera Vascongado v. S. S. Cristina, [1938] A. C. 485; the Government of the Republic of Spain v. S. S. Arantzazu Mendi, [1939] A. C. 256.

In Italy, on the other hand, the recent measure for partial land reform which provides for the expropriation and assignment to peasant proprictors of some $1,750,000$ acres of land, contains provisions for compensation to owners based upon the taxable value of the expropriated land, a quarter of which is paid in cash, the remainder being payable in 25 year Treasury bonds.

2 "Instead of owning its railroads, radio systems, or tclegraph and telephone lincs, the United Statcs has preferred to maintain private management with government regulation. . . . While there is some sentiment in the United States for public ownership of these properties, the bulk of the opinion secms to favour private status." Harold H. Zink, Government and Politics in the United States 642 (1947).

Examples of public ownership in the United States are the Tennessee Valley Authority, the Post Office, and the United States Maritime Commission.

3 The expression "state" is used throughout this essay because these nationalized industries were assigned to autonomous boards and are not operated by government departments on bchalf of the Crown; sce, for example, Tamlin v. Hannaford, [1950] r K. B. 18 (C. A. 1949). 
England today. There are two basic rules of English law which relate to this matter. In the first place, the compensation payable for the expropriated property, just like the expropriation itself of the property, must be authorized by Parliament. Secondly, when property is compulsorily acquired, the courts of law apply, in interpreting the statute which authorizes the expropriation of property, the canon of construction that express words are needed to authorize its taking without compensation.

With regard to the first principle, since in England the state, just like a private individual, does not possess any inherent powers of expropriating property, except by virtue of the Royal prerogative ${ }^{4}$ in time of war, it must seek special powers authorizing it to do so. Therefore, whenever it is the policy of any particular Government that property owned by private individuals be acquired for public purposes and that compulsory powers be exercised for its acquisition, it is necessary for the legislature to pass acts of Parliament in order to endow the appropriate statutory board with the requisite powers.

Moreover, not only are acts of Parliament necessary for the expropriation of property but they are also necessary for the payment of compensation for such expropriation, since the expenditure of public funds must be authorized by Parliament. So the provisions for compensation in respect of any particular industry which has been nationalized are considered by Parliament when the bill for the expropriation of the industry is before it and consequently the terms of the compensation authorized are embodied in the statute which empowers the state to acquire compulsorily the industry in question.

Secondly, in interpreting acts of Parliament which authorize the compulsory acquisition of property, the courts apply as a canon of construction, the rule of law that express words are needed for the expropriation of property without payment therefor. In other words, if it is the intention of the legislature that the property of an individual be compulsorily taken away from him without any compensation for the loss, then such an intention must be expressed in the expropriating statute in clear and unequivocal terms.

This canon of English law is really self-explanatory. It means that if it is the intention of the legislature to confiscate the property of private individuals it must express such an intention in plain terms, free from ambiguity and doubt, in the confiscatory statute. But, if the provisions of a statute which expropriates the property of private individuals are reasonably capable of being construed so as to avoid the expropriation of property without compensation "consistently with the general purpose of the transaction," ${ }^{, 5}$ they should be so construed. This canon of law applies to both partial and total confiscation of property and, a fortiori, to the construction of a statute delegating legislative powers. . $^{\text {. }}$

'The Government has power to deprive the subject of the possession of his property for the defense of the Realm in time of war: Attorney-General v. De Keyser's Royal Hotel, Ltd., [1920] A. C. 508.

31 Halseury's Laws of England 504 (2d ed. I939).

- Newcastle Breweries v. The King, [1920] I K.B. 854 . 
This rule of law was first evolved in the Middle Ages ${ }^{7}$ and has been followed and applied by the courts right down to the present time. For instance, in the case of Central Control Board (Liquor Traffic) v. Cannon Brewery Co. Led., ${ }^{8}$ in which a claim was made for compensation in respect of a public-house which had been acquired by the Board under powers conferred on them by the Defence of the Realm (Amendment) (No. 3) Act, $1915{ }^{8 *}$ and the Defence of the Realm (Liquor Control) Regulations, 1915, the former authorities on this point were referred to and Lord Atkinson in his judgment said:

That canon of construction is this: that an intention to take away the property of a subject without giving to him a legal right to compensation for the loss of it is not to be imputed to the Legislature unless that intention is expressed in unequivocal terms. I used the words "legal right to compensation" advisedly, as I think these authorities establish that, in the absence of unequivocal language confining the compensation payable to the subject to a sum given ex gratia, it cannot be so confined.

As Parliament is omnipotent ${ }^{9}$ there is, of course, nothing to prevent it from passing legislation which would empower the state to take property compulsorily without giving any right of compensation to the persons disappropriated. Such a policy has, however, never been adopted.

From at least as early as the sixteenth century, statutes were passed which both authorized the compulsory acquisition of land for public purposes and gave rights of compensation to the owners whose land had been so acquired. In 1542 , for instance, the Mayor and the Dean of the Cathedral City of Gloucester were empowered ${ }^{10}$ to provide a water supply for the city by bringing water in conduits from springs to it. The statute also provided for "satisfaction" to be given to the owners or possessors of ground used for the purposes of the act. A similar act ${ }^{11}$ was passed in 1544 relating to London which contained provisions for compensation to be granted to the owners of land taken for the act by the award of Commissioners appointed for the purpose by the Lord Chancellor, with a right to an action of trespass should the Commissioners fail to agree.

During subsequent centuries, acts of Parliament were passed which contained

${ }^{7}$ In the case of Sir Francis Barrington, (I6II) 8 Rep. $138 \mathrm{a}$, reference is made to the cascs of the Prior of Castleacre and the Dean of St. Stephens, (1503) I8 Hen. 7 Rot. 416 (unreported) quoted in Boswell's Case (1584), in which it was held that "when an Act makes any conveyance good against the King, or any other person or persons in certain, it shall not take away the right of any other, although there be not any saving in the Act."

${ }^{8}$ [1919] A. C. 744,752 . This followed the authority of many cases.

82 GEo. 5, c. 42.

- This power may be compared with the power of the Federal Government of Australia to pass a law nationalizing private banking. In Commonwealth of Australia v. Bank of N. W. Wales, [1950] A. C. 235, it was held that the Banking Act, 1947, Section 46 of which prohibited the carrying on in Australia of the business of banking by private banks, was invalid as contravening Section 92 of the Australian Constitution which provides that "rrade commerce and intercourse among the States ... shall be absolutely free," and that in so far as banking business is carried on by means of interstate transactions it is within the ambit of, and the freedom is protected by, that section.

${ }^{10}$ Bill for Conduyttes at Gloucester, 33 HEN. 8, c. 35.

1135 HEN. 8, c. Io. 
provisions of a similar nature ${ }^{12}$ relating to the compulsory purchase of land. Another important act which, however, did not relate to land, was the Act for the Abolition of Slavery in $1833^{12 a}$ which not only freed slaves in the British Empire but also gave to their owners compensation by way of cash payments. The total amount of compensation paid to the slave owners was $f_{20}$ million. This was distributed by Commissioners appointed for that purpose among nineteen regions, regard being had to the number of slaves registered in each region and to the price paid on the average of eight years ending on December 3 , $1830 .{ }^{13}$

As far as the compulsory acquisition of land was concerned, in each act the terms of the compensation were set out in full and it was not until $x 845$, when the Lands Clauses Consolidation $\mathrm{Act}^{1{ }^{1 *}}$ was passed, that a uniform code of rules was laid down which could be applied by the incorporation of the Act in a special act for the compulsory acquisition of property. These provisions are still in force today, but where under any act of Parliament, passed before or after September I, I9I9, land is authorized to be acquired compulsorily by a government department or a local or a public authority, any dispute relating to compensation must be determined according to the provisions of the Acquisition of Land (Assessment of Compensation) Act, Igrg. ${ }^{14}$

The compulsory purchase of land is but a preliminary step towards the nationalization of industry. It is, nevertheless, a matter of major importance as far as the right of compensation is concerned because the principle of granting a right of compensation to persons whose land has been expropriated was extended to include other types of assets which subsequently became acquired by the state.

The first type of industry to be expropriated in the twentieth century related to transport and its maintenance. In I908 the Port of London Authority ${ }^{15}$ was set up and to it were transferred the assets and undertakings of various companies which had owned and operated the docks in the river Thames. In consideration for the loss of their property the companies received specified amounts of "Port Stock" created under the terms of the Act. Again, in 1933, the London Passenger Trans-

\footnotetext{
12 There were some exceptions to the rule, e.g., the Turnpikes Act, I822 (3 GEO, 4, c. 126); also no compensation was awarded if the owner's property was of very small value, e.g., an interest in the subsoil: see the Public Health (London) Act, I891, 54 \& 55 Vicr., c. 76, \$44(2).

${ }_{122} 3 \& 4$ WrLL., c. 73 .

13 This worked out at an average rate of $£ 37.10$. per share. See D. Thompson, England In the Nineteenth Century.

132 8 \& 9 VICT., c. 16.

16 Compensation under this Act (9 \& 1o Geo. 5, c. 57) is based on the value of the land. This is the amount which the land, if sold in the open market by a willing seller might be expected to realize, but all returns and assessments of capital value for taxation made or acquiesced in by claimant may be taken into consideration. The Act has now been extended and amended by the Town and Country Planning Act, I947 (ro \& II Geo. 6, c. 5I), and Lands Tribunal Act, I949 (12 \& 13 Geo. 6, c. 42).

${ }^{25}$ The Port of London Authority Act, I908, (8 EDw. 7, c. 68), transferred the undertakings of the London and India Docks Company, Surrey Commercial Dock Company, and Millwall Dock Company to the Port of London Authority. The Port of London Authority issued to those companies amounts of " $A$ " and " $B$ " Port Stock as compensation by way of substitution for existing debenture and other stocks of dock companies which were cancelled by the Act.
} 
port Board was established and to it were transferred passenger transport undertakings owned both by companies and by local authorities within the area of the Board. ${ }^{16}$ The terms of transfer for the majority of the undertakings were contained in the Act, but where this was not done or an agreement could not be reached, reference could be made to an arbitration tribunal set up under the London Passenger Transport Act, 1933. Transport stock was issued in consideration of the compulsory acquisition of the property to both the companies and the local authorities who had formerly owned the undertakings..

The year 1938 saw the acquisition by the state of another type of property. In that year the Coal Act ${ }^{18}$ was passed under which all coal and mines of coal together with property and rights annexed thereto and certain rights to withdraw support, subject to certain servitudes and restrictive covenants, were acquired by the Coal Commission. Compensation ${ }^{19}$ was paid to existing owners for the acquisition of their interests according to provisions set out in the Act and consisted of sums of money ascertained by valuation of the interests that subsisted at the valuation date in coal, mines of coal, and acquired property and rights. ${ }^{20}$

\footnotetext{
${ }^{16}$ The London Passenger Transport Act, I933, $23 \& 24$ GEo. 5, c. 14, transferred to the Board the underground railways and tubes, railway system, London General Omnibus Company, Green Line and other coach companies, Metropolitan Railway, tramways of Hertfordshire, Middlesex and the London County Council, County Boroughs of West Ham, East Ham, Croydon, Boroughs of Barking, Ilford, Leyton and Walthamstow, urban district councils of Bexley, Dartford and Erith, as wcll as the tramways of the City of London and the London Omnibus undertaking of Tilling and British Automobile Traction, Ltd., the London Omnibus undertaking of Thomas Tilling Ltd., and independent omnibus undertakings.

${ }^{x 7}$ Section 7 provided that the Board "as consideration for the transfer" to it of underground and metropolitan undertakings was to issue stock created by the Act (Transport Stock); for the Tiling, independent, or Lewis undertakings, consideration was in cash or partly cash and partly 'Transport Stock. Consideration for transfer of undertakings of local authorities consisted of stock for the larger authorities and in certain cases the Board paid off the local authorities' liabilities, such as loans raised for their transport undertakings and interest thereon.

${ }^{18}$ I \& 2 GEO. 6, c. 52 .

${ }^{10}$ The Commission was required to pay as compensation to existing owners for the acquisition of their interests, sums of money in respect of all coal and mines of coal, of all acquired property and rights and of all rights to withdraw support that were vested in the Commission. Compensation was to be ascertained separately for (a) the above acquired interests (certain minerals and surface servitudes excepted) which were known as "principal coal hereditaments" and (b) the exceptions, which were referred to as "subsidiary coal hereditaments."
}

The aggregate amount of compensation payable in respect of the principal coal hereditaments was $£ 66,450,000$.

20 A Central Valuation Board was established to divide Great Britain into regions known as "valuation regions" and to allocate to each a regional allocation part of the aggregate amount of compensation.

The compensation was ascertained by valuing the "acquired interests" at the valuation date which subsisted in coal, of coal and acquired rights. The subject of each valuation was a unit known as a "holding," consisting of an acquired interest or of a group of such interests.

The value of a holding was the amount it might have been expected to realize if the Act had not been passed and it had been sold on the valuation date in open market by the existing owners as willing vendors to willing purchasers under a contract providing for completion on the vesting date. If there was also a right to withdraw support which was to vest in the Commission, it was to be valued as if each of the existing owners having power to grant such right, had agreed to grant it in addition to any acquired rights in which the holding subsisted. The amount was ascertained by the Central Valuation Board.

For each holding, in any valuation region for which compensation was payable, was paid (I) a sum 
During the World War of I939-45, plenary -powers were given to the British Government by the Emergency Powers (Defence) Act, $1939^{20^{2}}$ and regulations made in pursuance thereof, to enable it to prosecute the war with the utmost vigour. Under Regulations 55 and 78 of the Defence (General) Regulations, 1939, a government department could appoint a controller to take charge of an undertaking carried on by a company and in order to secure an effective control over the undertaking could transfer the shares of the company to specified transferees. The price to be paid for such shares was to be such price as might be specified in an order made by the Treasury, and not less than the value of such shares as between a willing buyer and a willing seller on the date of the order authorizing the transfer.

The failure to include in the Regulations a method for the valuation of any shares so acquired led to litigation when in pursuance of the Regulations the Minister of Aircraft Production made an order appointing a controller to take charge of an aircraft production firm, Short Brothers (Rochester and Bedford) Ltd, and by a subsequent order transferred the shares in that company to his nominees. The Treasury Commissioners specified the prices of these shares to be 22s. $3 \mathrm{~d}$. a share in respect of the 5 per cent Redeemable Cumulative Preference shares, 29s. $3 \mathrm{~d}$. a share in the case of the " $\mathrm{A}$ " Ordinary shares, and 29s. $3 \mathrm{~d}$. a share in the case of the Ordinary shares. This valuation was based on the prices ruling on the Stock Exchange on the date on which the controller was appointed although in fact the Regulations in question did not require use of the Stock Exchange quotation for the purposes of valuation.

Two shareholders were dissatisfied with the prices fixed for their shares, which they alleged should be 4Is.gd. a share, and contested the method of assessing the price used by the Treasury Commissioners. Consequently, an arbitrator was appointed to assess the value of the class of shares in question, namely, the " $A$ " Ordinary shares and the Ordinary shares. The arbitrator stated his award in the form of a special case for the opinion of the Court, and Morris, J., confirmed his award which supported the Treasury Commissioners' valuation. An appeal was brought by the two shareholders to the Court of Appeal and subsequently to the House of Lords. ${ }^{21}$

In the House of Lords it was contended by the appellants that as the transfer was a transfer of all the shares, the Stock Exchange value was not a true criterion and that it was improper to fix the value on the hypothesis of the purchase of individual blocks of shares from individual shareholders as the Treasury Commissioners had done. The appellants further argued that the appropriate method was first to ascertain the value of the whole undertaking and then to determine the proportionate

bearing to the amount certified as attributable to the principal coal hereditaments the same proportion as the amount of the regional allocation for that valuation region bore to the aggregate of the amounts so certified by the Board in respect of all such holdings in that valuation region; and (2) a sum equal to any amount certified as attributable to subsidiary coal hereditaments.

$202_{2} \& 3$ Geo. 6, c. 62 .

${ }^{21}$ Short v. Treasury Commissioners, [1948] A. C. 534 . 
value of the separate classes of shares, and of individual shares within each class. To this contention the respondents replied that the proper basis of valuation was to assume that the shares had been bought in individual blocks from individual shareholders on the date of transfer and to fix the value accordingly, and that that value was best ascertained from the prices ruling on the Stock Exchange on the relevant date, namely, when the controller was appointed.

The House of Lords upheld the Treasury Commissioners' valuation. In deciding that the Treasury Commissioners' contentions were right, their Lordships held that the Stock Exchange prices afforded a fair criterion of the value of each block of shares as between a willing buyer and a willing seller on the relevant date, although the Regulations did not require that the value of the shares should be fixed on the basis of the Stock Exchange prices.

Following, therefore, the historical development of the principle of compensation for the expropriation of property as briefly outlined here, when the Socialist Government of 1945 put into operation one of the principal tenets of its policy, namely, the nationalization of certain industries, a statutory right of compensation was invariably given for assets and interests acquired by the state. ${ }^{22}$ As will be seen, very detailed provisions are contained in the acts of Parliament which transferred the ownership of certain industries from private ownership and management to public control.

Since I945 various acts of Parliament have been passed, the object of which was the compulsory transfer of the assets of specified industrial undertakings from private ownership to public ownership exercised through centralized autonomous boards. These statutes include the Bank of England Act, ${ }^{23}$ the Cable and Wireless Act, ${ }^{24}$ and the Coal Industry Nationalisation Act, ${ }^{25}$ which were all passed in 1946.

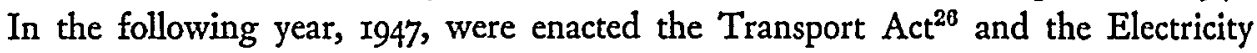
Act. ${ }^{27}$ The Gas Act, $1948,{ }^{28}$ was the next nationalizing statute to be passed, and this was followed by the Iron and Steel Act, $1949,{ }^{29}$ which has only just come into force.

The industries which have been chosen by the Socialist Government, which took office in England in 1945, to be the objects of their policy of nationalization differ

\footnotetext{
${ }^{22}$ It should be observed that the principle of compensation for the expropriation of assets is not followed by all Socialists, see for instance Mr. Shinwell's speech as Minister of Fucl and Power in which he said in the House of Commons, "There is a substantial body bf opinion in this country which is opposed to compensation ... indeed there was a time in the Labour Movement when compensation was regarded as a mistaken policy. We are much more reasonable nowadays, but we must not be too generous with public money." 422 H. C. DEB. 1542 (5th ser. 1946).

The attitude of the majority of Socialists towards this matter may be epitomized in the words of Professor W. A. Robson who writes: "Compensation is both economically necessary and socially desirable, but the need remains for seeing that it is not excessive." Public ENTERPRISE 385-386 (Robson ed., 1937).

${ }_{23} 9$ \& xo GEo. 6, c. 27.
10 \& II GEo. 6, c. 49.
29 I2 \& I3 GEo. 6, c. 72.

249 \& I0 GEO. 6 , c. 82 .

as 9 \& to Gro. 6, c. 59.

${ }^{27}$ IO \& II Gro. 6, c. 54 .

${ }^{38} 11$ \& 12 GEo. 6, c. 67.
} 
fundamentally not only in nature and type, but also in operation and administration. For instance, the coal mining industry is totally unlike the transport or gas industries, in the type of material produced, main features of operation, and general management. Further, this industry differs from the latter industries in as much as it was entirely controlled by private or public companies, while the latter were owned sometimes by private or public companies, and sometimes by local authorities and public boards.

Moreover, not only are there basic distinctions between the different industries which have been expropriated, but different methods have been employed to effect their nationalization. For example, in some cases the whole undertaking has been transferred to the new central body entrusted with the task of administering the nationalized industry; whereas in others the capital assets only have been transferred, leaving the administration in the hands of the former owners, direction of policy and financial control only being exercised by the state body, as for example, in the case of the iron and steel industries.

As may well be expected, as a result of the diversity of the types of industry affected by nationalization and the different methods employed to transfer these industries from private to public ownership and control, many distinctions have inevitably been made in respect of the terms of compensation awarded to those persons whose interests and assets in the different industries concerned have been transferred to the state. In order, therefore, to give a clear and comprehensive picture of the compensation which has been awarded to persons whose interests and assets have been expropriated, it is necessary to consider not only the terms of the compensation, but also the different types of assets involved in the transfer, and different classes of owners who have been compensated.

The policy of the legislature in regard to the nationalization of certain industries has been to transfer the "securities" of the industries from private to public ownership. This means that the capital stock only of the industries concerned is transferred to the state. In cases such as these, the actual plant and management is not directly transferred to the state but the industry is managed by the state through the exercise of financial control and direction of general policy.

As far as certain industries are concerned, such a policy might well be expected. In the banking industry, ${ }^{30}$ for instance, the whole of the capital stock (i.e., bank stock) of the Bank of England was transferred by the Bank of England Act, 1946, ${ }^{31}$ to a nominee of the Treasury to be held by that person on behalf of that department. So with the expropriation of the bank stock, the Government acquired control over the activities of the Bank and can dictate its policy.

The persons who were entitled to be compensated under this Act consisted of those persons who immediately before the appointed day, March r, I946, were

\footnotetext{
${ }^{30}$ The reader's attention is here drawn to the fact that private banks in England have not so far been nationalized.

${ }^{31} 9$ \& 10 GEO. 6, c. 27.
} 
registered in the books of the Bank as the holders of any bank stock. These stockholders were compensated for the loss of their shares by the award of substituted stock created specially by the Treasury for the purpose of compensation, known as "government stock."

The amount of stock which each former stockholder of the Bank was given as compensation was the amount necessary to give such stockholder, by way of interest thereon, an annual sum equal to the average gross annual dividend declared by the Bank during the twenty years preceding March 3r, I945. As the Bank paid a fixed annual dividend of $\mathrm{I2}$ per cent for the twenty-three years before that date, and as the interest on the government stock is determined under the Act to be 3 per cent, the Treasury had to issue sufficient stock at 3 per cent to enable a stockholder to have the same income which he formerly had from the stock yielding 12 per cent. ${ }^{32}$ The interest on the government stock is payable every half year, in April and October. It will be continued to be paid until April 5, 1966, on or after which date the Treasury may redeem the stock at par.

A similar instance in which the stock only of an industry was transferred to the state is that of the company known as Cable and Wireless Ltd. This company had been formed as an operating company to hold and operate all the communication assets of certain submarine cable companies and of a wireless telegraph company as well as certain cables previously belonging to the Governments of the Commonwealth and beam wireless stations in the United Kingdom. The cable companies and the wireless telegraph company had received in exchange for the transfer of their assets to Cable and Wireless Ltd., all the shares issued by that company, so that they became holding companies in it. Some shares were, however, transferred to nominees of the Treasury in 1938 when the freehold of the beam wireless stations formerly leased to the company was transferred to the Treasury. In 1945, therefore, when the Government decided that the company should be publicly owned, the shares of the company were owned by both the holding companies and the Treasury. The Cable and Wireless Act, $1946,{ }^{33}$ was consequently passed in order to transfer the shares of the Company, other than those already held by the Treasury, to nominees of the Treasury for payment of compensation to the shareholders.

This case differs from the previous one because the owners who received compensation for the loss of their shares were not private stockholders but companies numbering nine altogether. The compensation which they received consisted of the issue of government stock of a value equal, on the date of the issue, to the amount of the company's compensation, having due regard to market values of other government securities existing at such date, together with interest thereon from the appointed day, which was January I, I947. The amount of each company's compensation was agreed upon between the company and the Treasury or in

\footnotetext{
${ }^{32}$ This is four times the amount of the bank stock and amounts to $£ 58,212,000$.

${ }^{33} 9$ \& to Geo. 6, c. 82.
} 
default of agreement, determined by a tribunal set up by the Act. The Act contains detailed provisions to be applied by the tribunal in coming to a determination. ${ }^{34}$

An entirely different type of industry has been nationalized according to the same policy. This is the iron and steel industry, the last of the industries to be nationalized under the I945 program of the Socialist Government and which is expropriated by the Iron and Steel Act, r949..$^{35}$ The scheme of nationalization adopted in this instance consists of the compulsory acquisition of all the "securities" of ninety-two named companies which are engaged in the iron and steel industry and their transfer to the Iron and Steel Corporation set up by the Iron and Steel Act, r949. The companies involved thus became publicly instead of privately owned, under the control of the Corporation.

The "securities" of a company which were compulsorily acquired under this Act have been defined by the Act to mean any shares, debentures, debenture stock, loan stock, mortgages, income notes, income stock, funding certificates, and securities of a similar nature. But they do not include any security forming part of the loan capital of the company which may be redeemed, either without notice or at one year's notice, at a price not exceeding the actual amount of the security together with any outstanding interest, at any time after the security has been created or when not less than one year has expired after it has been created; nor do they include any security forming part of the loan capital of the company which was issued after July I6, I945, and before October I, I948, and the terms of which require it to be redeemed within a period of ten years and seven days after its date of issue.

Compensation is to be satisfied under this Act by the issue of government stock, called British Iron and Steel stock, specially created and issued by the Corporation for that purpose. This stock may be issued by the Corporation on such terms and conditions as the Corporation with the consent of the Minister and the approval of the Treasury may determine. As, at the time of writing, the Iron and Steel Act, I949, is not fully operative, no stock has yet been issued so that it is impossible to give any details relating to the interest payable upon the stock and similar matters. ${ }^{35}$

The owners to whom compensation is payable are the persons who, immediately before the date of transfer, were the holders of any securities with values determined before that date, or were the holders of any securities during the period between the date of transfer and the conversion date, who are entitled to certain rights. They become on that date the holders of the amount of British Iron and Steel stock to which they are entitled under the Act in satisfaction of compensation payable in

\footnotetext{
${ }^{34}$ This consisted of three members who were required to ascertain the amount which the operating company's undertaking might be expected to realize if sold in the open market on the appointed day as a going concern by a willing seller to a willing buyer on the basis of the net maintainable revenue and the number of years' purchase to be applied thereto. The amount so ascertained was taken as being the aggregate value of the issued share capital of the company and the amount of each company's compensation was the proper proportion of that value as determined by reference to the number of shares held by the company as set out in the Act.

${ }^{35}$ I2 \& I3 Geo. 6, c. 72.

${ }^{30}$ Value of iron and steel securities which vested on February 15 , I95 $\mathrm{T}$, is about $£_{300}$ million.
} 
respect of the securities. The amount of compensation which is awarded to such persons is the amount of British Iron and Steel stock which in the opinion of the Treasury was at the general date of transfer of a value equal to the value of the securities acquired, regard being had in estimating the value of the British Iron and Steel stock so issued to the market value of government securities at or about that date.

The value of the securities which have been expropriated, was for the purpose of compensation, determined by the dates on which they were quoted on the Stock Exchange or issued. So, as it will be seen, a different valuation was given under the provisions of the Iron and Steel Act, 1949, in respect of those securities quoted on the Stock Exchange in 1945 and 1948 , to those quoted after dates specified in I 945 and before specified dates in 1948 , and to those issued after the specified dates in 1948 .

In the first place, when securities were quoted on certain dates in 1948 and in 1945, the value of these securities is ascertained by taking the average of the mean of the quotation ${ }^{37}$ for securities of that class appearing in the Stock Exchange Official Daily List on specified dates in 1948, or appearing in that list or the Stock Exchange Daily Supplementary List on specified dates in 1945, whichever was the higher. ${ }^{38}$ Secondly, if a new class of securities has been issued after the dates specified in 1945 and before the first date specified in 1948 and the securities were quoted in the Stock Exchange Official Daily List on all the dates in 1948 , the value of those securities is deemed to be the average of the mean of the quotations for securities of that class appearing in that List on the specified dates in 1948. If in the case of either of these two classes of securities a fresh issue of securities has been made after the last relevant quotation date, the value of every security of that class is to be deemed to be the average of the values of all the securities of that class calculated on the basis that the value of each of the securities comprised in that issue is the price at which it was issued or, if it were issued free, nil, and the value of the remaining securities is the value which those securities had or would have had for the purposes of this provision immediately before the issue took place.

In the third place, as far as a class of securities which has been issued on or after the specified dates in 1948 is concerned, the value of such securities is to be deemed to be the price at which they were issued. If they were issued free, their value is deemed to be nil and the provisions relating to the issue of fresh securities or conversion of securities are to apply to any fresh issue or conversion of securities of that class. $^{39}$

\footnotetext{
${ }^{37}$ The mean of the quotations means the average of the two figures shown in the Stock Exchange Official Daily List or Supplementary List, on the dates in question in respect of the security in question under the heading "quotations" or "nominal quotations."

${ }^{38}$ Such an addition, if any, being made to the higher average as was necessary to make it a complcte multiple of one penny.

${ }^{30}$ The value of securities comprised in the first three classes of securities mentioned, converted after the last relevant quotation date into securities of a different nominal value, was deemed for the
} 
The Act also contains provisions which are to be applied to the valuation of securities in two special cases. These consist of the cases in which all the securities of any issue were originally disposed of to a person who did not become the registered holder of them, ${ }^{40}$ and where securities have been issued by a company to another company in consideration of the transfer of property belonging to the latter company to the former company. ${ }^{41}$ Finally, provision is made for the valuation of any securities which do not fall within any of the classes specified above. The valuation of such securities is to be determined by agreement between the stockholders' representatives ${ }^{42}$ and the Minister of Supply. In default of such agreement, the matter is transferred to an arbitration tribunal set up under the Act.

These provisions relating to the value of securities for the purpose of compensation under the Iron and Steel Act, I949, ${ }^{43}$ are complicated and tedious. But, they have been deliberately set out in order to show the details which the legislature has considered to be necessary for insertion in the Act in order to fix the precise terms of compensation which in its opinion are adequate to recompense the owners who have suffered loss of their property. The inclusion of these detailed provisions in the Act itself has the result of both empowering the Corporation to spend public money by way of issue of stock in satisfaction of compensation while at the same time delineating its powers to award compensation, and of assuring to the disappropriated owner, not only a right to compensation but also the details of what he is likely to expect.

It is interesting to compare the policy of the legislature in regard to the nationalization of the iron and steel industry with that which it adopted to nationalize the coal mining industry on account of the radically different measures which were employed in each case. The main distinction between the two methods adopted is that whereas with regard to the iron and steel industry, the assets transferred to the state consisted of the securities of the companies to which the Iron and Steel Act, 1949, applied, in the case of the coal industry, the assets of the companies en-

purposes of compensation under this Act, to be a value bearing to the value which the securitics had or would have had for the purposes of this provision immediately before the conversion took place, the same proportion as the nominal value of the securities so converted had to the nominal value of the securities immediately before the conversion took place. Further, the provisions relating to the fresh issue of securities applied to any fresh issue of securities which have been so converted, but if a part only of a class of securities had been so converted, the converted securities were to be treated as securities of a different class from that of the unconverted securities.

${ }^{10}$ The price was (a) the price paid for that security by the first registered holder thereof, or (b) the price received by the company for the security together with an amount equal to $2 \frac{1}{2}$ per cent of that price, whichever was the lower.

"I The value of the securities of the transferring company was first determined as above, as though such transfer had not taken place. The aggregate value must then be apportioned as between the sccurities of the transferring company and the securities so issued as determined by the stockholder's representative or by arbitration.

"2 This is a person appointed for each company by the holders of securities at a meeting called for that purpose. In default of such appointment, the Minister makes the appointment. He calls meetings of the stockholders and acts as their representative in negotiations with the Minister.

43 12 \& I3 Geo. 6, c. 72. 
gaged in that industry which were expropriated comprised the actual mines, colliery plants, and physical assets of the companies. This distinction in the measures used to nationalize these two great industries is reflected in the methods employed to compensate owners who have been disappropriated. In the former case compensation is given for the loss of securities, while in the latter case compensation was awarded in respect of the different classes of assets which were compulsorily acquired.

The assets of the companies which were engaged in the coal mining industry and which were acquired by the state under the Coal Industry Nationalisation Act, I946, fall into three main categories. The first class consists of those assets which vested by virtue of the Act in the Coal Board on the "primary vesting date" and which were transferred to the Board without option. ${ }^{44}$ The second class comprises certain assets which were transferable to the Board at the option of either the Board or the owners of the assets, ${ }^{45}$ while the third class consists of assets which were transferable at the option of either the Board or the owners of the assets subject to arbitration in the case of objection by either side. ${ }^{40}$ Certain other interests have also been transferred to the Board. These included certain interests in patents and designs which were transferable to the Board at the option of either the owners or the Board subject to arbitration in the case of objection. All rights and liabilities attaching to the assets transferred to the Board also passed to it. All these rights, assets, and interests which became vested in the Coal Board under the Act are known as "transferred interests" and are referred to accordingly.

The compensation payable under the provisions of the Coal Industry Nationalisation Act, $\mathrm{I} 946$, was paid with reference to these transferred interests. The values of these transferred interests were assessed separately for two different purposes in regard to compensation. In the first place, it was ascertained in respect of what was known as their "coal industry value." This means their value so far as was determined under the provisions of the Act to be attributable to their usefulness for activities relevant to district wages ascertainment which are defined by the Act to be the periodic ascertainments of the results of the coal industry in accordance with which the wages of mineworkers have been regulated under agreements made for that purpose between colliery owners and mineworkers. Secondly, it was ascertained in respect of their value for "subsidiary purposes," namely, for any purposes which did not fall within the first category.

Each transferred interest was assessed by the Minister of Fuel and Power

4t These include unworked coal and mines of coal; collieries, coke ovens and manufactured fuel plants; colliery electricity plants; colliery transport, loading and storage works; colliery merchanting property; colliery institutes etc.; maintenance; operation, office and gencral equipment; stocks of colliery products; and certain curtilages and development sites.

${ }^{4}$ These comprised colliery stores; waterworks; certain wharves etc., used for colliery purposes; housing property; and farming property.

so These consisted of manufactured fuel plants other than those of collieries; certain transport loading and storage works other than those of collieries; associated merchanting property; central reserve stations; brickworks; curtilages and development sites not within those referred to in note 44, supra, and other colliery assets of any kind except iron and steel works. 
according to whether its value could be attributed, either as a whole or in part, to usefulness for activities relevant to district wages ascertainments. If a part only of a transferred interest was so assessed, then the Minister decided to what extent the part involved could be so attributed. The Minister's decision was subject to determination by two accountants in the case of objection and then to arbitration in the event of their failure to reach agreement.

For the purposes of compensation, the transferred interests were grouped into units called "compensation units." These units were constituted by the Minister so as to include in each such unit every transferred interest. In deciding how the transferred interests were to be dealt with as regards their arrangement in compensation units, the Minister was required to treat as the normal compensation unit, subject to variations in special circumstances, a unit consisting of all the transferred interests of a single colliery concern or other owner which were in property situated permanently in, or ordinarily separated from, a single district and which were not subject to different incidents as respects the ascertainment of compensation.

The compensation units were allocated to certain districts which were prescribed by the Minister to be "valuation districts" for the purposes of the Act. They corresponded with the districts for which district wages ascertainments were made for the purposes of the adjustment of wages payable in 1939. The Minister could, however, if it were more convenient, create a valuation district for two or more such districts or vice versa.

After the transferred interests had been valued in respect of the two purposes mentioned above, and had been grouped into compensation units allocated to valuation districts, the value of each compensation unit itself was assessed. This was ascertained by a board for each district which was specially set up for the purpose and called the "District Valuation Board."

Each Board was required to determine the value of the compensation unit. This was taken to be the amount which it might have been expected to realize if the Act had not been passed and the unit had been sold on the primary vesting date in the open market by a willing seller to a willing buyer, no allowance being made because the vesting of the transferred interests comprised in the unit was compulsory. The Board had also to state what proportion of the value of the compensation unit was a coal industry value and how much of it was the value for subsidiary purposes.

As far as the sale in open market is concerned, this does not mean a purely hypothetical market free from any restrictions imposed by law but a sale having regard to all the circumstances which existed at the time, i.e., on the primary vesting date, on which it was deemed to have taken place. For instance, the undertaking of a colliery company ${ }^{47}$ was assessed for compensation purposes according to the provisions of the Act as stated above and the amount of compensation payable in respect of it was fixed by the Northern District Valuation Board. The company

${ }^{47}$ Priestman Collieries Ltd. v. Northern District Valuation Board and Anor., [1950] 2 All E.R. I29. 
agreed to the amount with the exception of the amount awarded for their mining timber which they contended should have been valued at a higher price than that awarded by the Board.

A case having been stated by a referee, the Court held that the assumed sale was to be taken as subject to the conditions under which willing buyers and sellers in Great Britain could legitimately have operated on the primary vesting date and that the requirement of the Act that regard should be had to all relevant circumstances showed that what was contemplated was a sale in the actual market, rebus sic stantibus. As at the time of the vesting date there was in force an order fixing the maximum prices of timber, the sale of the colliery timber in question must have been taken as subject to the provisions of that order so that the value as determined by the Board was held to be the correct one, the Board having taken the provisions of the order into account when fixing the value.

Compensation could also be awarded in respect of overhead-expense increase which had been caused by the severance of transferred interests from the assets of a business which included but did not consist entirely of transferred interests, and which could not reasonably be avoided. The amount was determined by the District Valuation Board with reference to the loss sustained at any time during the five years beginning with the primary vesting date. As well as this compensation, provision was also made for the award of compensation to a colliery concern in respect of a refund of capital expended by it in providing or improving any transferred interest when such expenditure was authorized by the Minister and was incurred on or after August I, I945. Such a refund was separate from the ordinary compensation and the value of a compensation unit as determined by a District Valuation Board, was reduced by the amount of the refund.

The aggregate amount of compensation which has been made in respect of the coal industry value of all the transferred interests was a sum which has been arrived at under an agreement made for this purpose before the passing of the Coal Nationalisation Act, 1946, between the Minister of Fuel and Power and the Mining Association of Great Britain, by the Coal Industry Compensation Tribunal. This Tribunal, which was presided over by Lord Greene, fixed this sum at $\oint_{1} 64,660,000$. This amount has been apportioned among the valuation districts by the Central Valuation Board which has been established by the Act for that purpose.

The amount of compensation which was made in respect of a compensation unit which had been allocated to a valuation district was the aggregate of an amount bearing the same proportion to what was certified to be the coal industry value of that unit-as the amount apportioned to that district bore to the aggregate of what was so certified to be the coal industry values of all compensation units allocated to that district in respect of which compensation was made, and an amount equal to what was certified to be the value of that unit for subsidiary purposes.

The persons to whom compensation was payable in respect of transferred interests 
fell into three categories. In the first place, if the compensation unit included only transferred interests of a company, none of which was subject to any charge or lien for securing money or to any other restriction, right, or liability from which it is freed by the Act, it was the company which was entitled to the compensation. Secondly, if a compensation unit included only the transferred interests of a person other than a company and none of those interests was subject to the charges or liabilities mentioned above, then that person was the person entitled to compensation. Finally, in any other cases, the person entitled to receive the compensation was the person designated by regulations made to safeguard the rights of persons entitled to beneficial interests in the compensation and the person designated might be an officer of a prescribed court or trustees appointed by the Minister.

As far as the mode of satisfaction of compensation is concerned, this took the form of the issue of government stock, apart from three cases. In the first place, compensation in respect of a compensation unit which comprised interests arising under a former freeholders' lease was satisfied by a money payment. ${ }^{48}$ Secondly, the amount of compensation in respect of any compensation unit which was equal to the value of the unit so far as attributable to stocks of products of colliery production activities, or to consumable or spare stores as specified by the Act, was satisfied by a money payment. Finally, certain other cases were also satisfied by money payments if the Minister considered it expedient to do so. But apart from these specified cases, all compensation, including that in respect of overhead-expense increases, had to be satisfied by the issue of stock. ${ }^{482}$

This outline of the main provisions relating to compensation in respect of assets nationalized under the Coal Industry Nationalisation Act, 1946, shows that in contradistinction to the terms of the Iron and Steel Act, I949, a complicated system of administrative machinery was set up to assist in the assessment of the values of assets for the purposes of compensation. So, a special tribunal was established to assess the total amount of compensation payable in respect of the total assets nationalized. Also, district valuation boards were set up for the purpose of assessing the values of compensation units. The compensation stock was actually issued by the Coal Commission itself. The special nature of the industry and the method of its nationalization required special measures relating to compensation which were not necessary in the case of the iron and steel industry in which the securities of the firms engaged in the industry were expropriated.

The method adopted to nationalize the transport industry is similar to that employed in regard to the coal industry. In each case physical assets were acquired by the state, but whereas in the former industry the owners who were disappropriated were exclusively private individuals, as far as the transport industry is concerned, the owners whose assets were expropriated included not only private persons and companies, but also local and public authorities, such as the London Passenger Trans-

${ }^{48}$ This was an interest which arose under the Coal Act, 1938.

"sa Refunds of capital outlay, as described supra, were also satisfied by money payments. 
port Board to which, as has been mentioned, the transport undertakings of private companies had already been transferred in r933. This multiplicity in ownership has had the effect of further complicating the matter of compensation.

The nationalization of transport is of particular interest on account of the different types of transport concerned. These included not only road transport of various kinds, but also rail transport and transport using inland waterways or canals. As a result of the distinct types of transport involved, the Transport Act, $1947{ }^{40}$ is divided into several parts which deal with the different types. Thus Part II of the Transport Act, 1947, deals with railways and canals, Part III of the Act contains the provisions relating to road haulage transport, while under Part IV of the Act, schemes may be made relating to passenger road transport and trading harbor undertakings. This separate treatment is particularly necessary as far as compensation is concerned, because different methods of awarding compensation are provided by the Act, in regard to railway and canal undertakings on the one hand, and road transport undertakings on the other.

As far as railways and canals are concerned, the whole of the undertakings of certain bodies specified in the Transport Act, 1947, were vested in the Transport Commission on January $\mathrm{r}$, r948. These comprised all the railway, canal, and inland water navigation undertakings in Great Britain which were subject to the control of the Minister of Transport, at the date of the passing of the Act, under an order made pursuant to Regulation 69 of the Defence (General) Regulations, 1939. Undertakings which were carried on to a preponderant extent outside such control were excluded from the Act, but not those which were carried on only to a limited extent. As can well be imagined, the state then acquired a variety of assets. These included not only railway lines, stations, and rolling stock, canal waterways, warehouses, and port facilities, but also hotels and other amenities for the traveling public.50

The compensation which was paid in respect of the acquisition of these undertakings, was not paid by reference to their assets, but by reference to specified securities of the undertakings as set out in the Act. No other form of compensation than this was payable except as expressly provided by the Act.

The amount of compensation which was payable was fixed at a figure equal to the aggregate value of the securities of the various undertakings which had been acquired by the state. But when securities issued by one body were all owned by other specified bodies, those securities vested in the Commission as part of the property of those other bodies, from which it follows that no compensation was paid to the body which issued them.

As far as the valuation of these securities is concerned, this had been calculated

to Io \& II Geo. 6, c. 49.

${ }^{50}$ The following were transferred to public ownership: 60 railway undertakings, 52,000 miles of track, r,230,000 wagons, 45,000 passenger coaches, 20,000 locomotivcs, 25,000 horse drawn wagons, 70 hotels, 50,000 houses, $x, 640$ miles of canals and waterways, and 100 steamships; 437 H. C. Deb. 36 ( 5 th ser. 1947). 
prior to the passing of the Act, and was specifically included in it. ${ }^{51}$ These values were determined by taking the average of the mean of their quotations in the Stock Exchange Official Daily List on specified dates, or, when they were quoted in the List on other specified dates, known as alternative dates, and their values were higher than those quoted on the former dates, the average of the mean of the quotations for those dates. Where the quotations were expressed otherwise than in terms of price values of $\oint_{\mathrm{I}}$ I00 nominal of acquired stock, the compensation values were

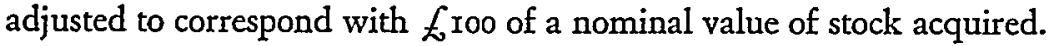

If securities were acquired which did not have a market quotation or were not quoted on the Official List on the days specified, an arbitration tribunal specially set up by the Act for the purpose, was empowered to determine their values, on application by the Commission. In assessing their value, the tribunal was required to have regard to the values specified in the Act for those securities just previously mentioned, which were most nearly comparable with the securities in question.

The Transport Act, I947, also contains provisions to be applied in valuing securities in special circumstances. So, where all the securities of a certain specified description were held by a local authority, their value could be agreed upon between the local authority and the Minister of Transport instead of by way of arbitration, and the amount so determined was the value of these securities for compensation purposes. Securities guaranteed by the Treasury were deemed to have a value equivalent to their nominal value.

With regard to the compensation being awarded in respect of railway, canal, and inland water navigation undertakings which belonged to local authorities, the only compensation which was payable in respect of such undertakings was an amount of money which would cover any payments due on or after the date of transfer for redemption of securities or repayment of loans made by the local authority for the purposes of the undertakings, together with interest thereon. Certain additional compensation might, however, also be given in certain circumstances.

Special provisions are contained in the Act with regard to privately owned railway wagons. Railway wagons which at the date of transfer were under a requisition order of the Minister made under Regulation 53 of the Defence (General) Regulations, 1939, vested automatically in the Commission and compensation could not

Ex These are some examples of the values specified in the Act Schedule Four:

Body by which security
was issued.
G.W.R.
G.W.R.
L.M.S.
L.M.S.
L.N.E.R.
L.N.E.R.
S.R.
S.R.

\begin{tabular}{|c|c|}
\hline Security & $\begin{array}{l}\text { Value of Security (per } \\
\text { Eroo nominal value) } \\
\text { for compensation. }\end{array}$ \\
\hline $\begin{array}{l}21 / 2 \% \text { debenture stock } \\
5 \% \text { debenture stock } \\
4 \% \text { debenture stock } \\
\text { ordinary stock } \\
3 \% \text { debenture stock } \\
4 \% \text { first preference stock } \\
5 \% \text { debenture stock } \\
\text { deferred ordinary stock }\end{array}$ & 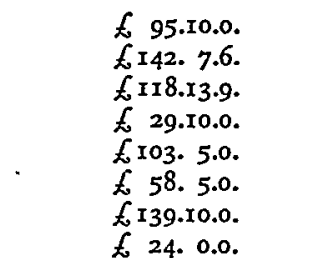 \\
\hline
\end{tabular}

The total amount of compensation paid in respect of these four railways was $f_{9} 90,000,000$. 
be claimed by the owners for any damage done to the wagons during the time they were requisitioned. Compensation was, however, payable in respect of the compulsory acquisition by the Commission of these railway wagons. Broadly speaking, the amounts which were paid as compensation were specified in the Act, Schedule Six of which sets out in detail the relevant sums calculated according to the type of wagon and the year in which it was built. ${ }^{52}$ These amounts were paid to the person who, immediately before the date of transfer, was the owner of the wagon. If, however, any of the wagons were the subject of a hire-purchase agreement the hirer could claim a portion of the compensation. Where a wagon was subject to a mortgage or incumbrance, the compensation was payable to the incumbrancer, if the charge was registered under the Companies Act, $1947,{ }^{52 a}$ or as a bill of sale.

With regard to the other type of transport acquired by the state, namely, road transport, the Transport Act, r947, contains provisions for the acquisition of all long distance road haulage undertakings whose activities should essentially be coordinated with rail transport. This necessitated the transfer of undertakings which came within a defined formula of acquisition, those operating the carriage of certain goods, however, being specially excluded.

As far as compensation for road haulage transport is concerned, this was not paid in reference to the securities of the undertaking whose vehicles were affected but in respect of four separate matters. In the first place, compensation was payable in respect of any goods vehicle which had vested in the Commission, equal to the cost, as at the date of transfer, of replacing the vehicle by a new vehicle of a similar type, subject, however, to depreciation at the rate of one fifth per year (one seventh in the case of rigid trailers) on the reducing figures for every completed year since the vehicle was first registered, and to deterioration in condition. Secondly, compensation was paid for any property vesting in the Commission, other than a goods vehicle, the compensation being equal to the amount which the property would fetch if sold in the open market, estimated as at the date of transfer, and as if the Act had not been passed. In the third place, compensation was given for cessation of business, the amount being paid to a person whose business has either totally or partially ceased as the result of the operation of a notice of acquisition, being calculated on the basis of the net annual profit as defined in the Act, and being not less

\footnotetext{
${ }^{52}$ Figures are given for various types of wagons and they depreciate in value according to their age. Here are a few examples:

An 8 ton wagon built in 1946 was worth $£ 248$

An 8 ton wagon built in 1933 was worth $£_{146}$

An 8 ton wagon built in 1919 was worth $£ 74$

An 8 ton wgon built in 1903 was worth $£$ ig

An $12 / I_{3}$ ton all steel wagon built in 1946 was worth $£_{3} 306$

An $12 / 1_{3}$ ton all steel wagon built in 1937 was worth $f_{0} 169$

An $12 / 13$ ton all steel wagon built in 1917 was worth $£_{22}$

A 21 ton hopper (all types) built in 1944 was worth $£ 430$

A 21 ton hopper (all types) built in r930 was worth $£ 232$

A 21 ton hopper (all types) built in 1917 was worth $£ 47$

E3x IO \& II GEo. 6, c. 47.
} 
than twice nor more than five times the net annual profit, regard being had in calculating such amount to the net annual profit which might have been made but for the Act. The last head covers the case in which compensation has been given for severance of property which has occurred because the activities of an undertaking consisted in part of operating vehicles which have been acquired by the Commission under the Act, and also of other activities which after the transfer of the vehicles are still carried on by the undertaking. In such a case, if it appears that the overhead expenses have increased in proportion after the transfer, the Commission had to pay to the transferor an amount of compensation in respect of the severance, as fairly represents the burden of that increase over the five years beginning with the date of transfer, provided that such increase could not have reasonably been avoided by the transferor. Special provision is also made in the case of property which is subject to a hire-purchase agreement, for making deductions from or additions to the total amount of compensation payable in respect of an undertaking in certain cases, and for property subject to incumbrances.

The position with regard to passenger road transport is not altogether clear. This form of transport service means a service of express carriages, stage carriages, tramcars, or trolley vehicles carrying passengers. It was not directly transferred to the Commission by the Transport Act, 1947, but the Commission is empowered by that Act to make a scheme to provide adequate, suitable and efficient passenger road transport services for any area. Such a scheme may require a designated body to provide these services instead of the Commission itself, and it may transfer the passenger road transport undertaking either to such a body or to itself. The provisions relating to compensation in respect of railway and canal undertakings in Part II of the Transport Act, I947, are incorporated in schemes made in respect of passenger road services.

The compensation which was payable to the owners of the expropriated property and whose interests have been affected by the operation of a notice of acquisition made under the Act, subject to the exceptions given below, was satisfied by the issue to them of the appropriate amount of British Transport Stock. The stock, created and issued for the purpose of satisfying any right to compensation, was such amount of stock as was, in the opinion of the Treasury, equal in value at the date of issue to that appropriate amount, regard being had to the market value of government securities at that date.

The British Transport Stock was issued and dealt with upon such terms and conditions as were prescribed by regulations made by the Minister with the approval of the Treasury. In exercise of this power, the British Transport Stock Regulations I947 were made. These contain provisions as to issue and redemption of stock, maintenance of a stock register and stock certificates, payment of interest and redemption moneys, and various miscellaneous matters. The interest on the stock is payable every half year, and it has been determined to be 3 per cent. 
In certain cases a money payment could be made in lieu of the issue of British Transport Stock in satisfaction of compensation. For instance, if the total amount of compensation to be paid to a person at any date was less less than $\$ 2,000$, on being given written notice by the person to whom it was to be paid, the Commission could pay in cash up to $f_{2}, 000$, and interest thereon from the date of transfer. Additional compensation in cash could also be given to a body whose undertaking is acquired by the state under a scheme made by the Minister of Transport under Part IV of the Transport Act, 1947. Again, if the total amount of compensation due to any one person in respect of his railway wagons which have vested in the Commission, did not exceed $\$ 2,000$, it could be paid in cash. As far as local authorities are concerned, not only did they receive lump sums in respect of their railway and canal undertakings which have been acquired by the Commission, but they may also receive additional compensation in cash in respect of all undertakings which could be transferred to the Commission under a scheme made by the Minister under Part IV of the Transport Act, 1947.

An analysis of the methods of compensation which were applied by the legislature in the Transport Act, I947, to the various kinds of transport undertakings which vested in the British Transport Commission shows that they combine in one Act all the different methods applied to the industries already discussed by different acts of Parliament. Therefore, not only is there compensation based on the value of securities, but also for specified assets, e.g., railway wagons, and goods vehicles. So, also, it takes the form both of the issue of stock and of cash payments.

The last two nationalized industries to be considered for the purposes of compensation, are the electricity and gas industries which were nationalized by the Electricity Act, I947, ${ }^{53}$ and the Gas Act, $1948 .^{54}$ As, in contradistinction to the nationalized industries already discussed, these two industries have certain features in common, the provisions relating to compensation in respect of the undertakings operating these services which have been acquired by the state, may conveniently be considered together.

In the first place, the whole of the rights, property, liabilities, and obligations of certain undertakings vested in the British Electricity Authority or the British Gas Council by virtue of their respective Acts. In the case of the British Electricity Authority, these consisted of statutory undertakings including local and public authorities, composite companies, and certain subsidiary bodies; power station companies; and electricity holding companies; while in regard to the British Gas Council, they comprised statutory undertakings, local authorities and composite companies, non-statutory undertakings, ancillary companies, and certain defined holding companies. All the bodies, the whole of whose undertakings were expropriated, except local authorities, were dissolved by the Act in question.

Secondly, compensation was paid in respect of the nationalization of both in-

s8 Io \& II GEO. 6, c. 54 .

54 II \& I2 GEo. 6, c. 67. 
dustries to the owners of securities of the undertakings affected. These comprised the holders of securities, ${ }^{\text {jo }}$ i.e., any shares of stock, debentures, and debenture stock of the undertaking in question, immediately before the vesting day.

In the third place, the basis for valuation of the securities was the same. Under the Electricity Act, I947, the securities were valued if they had been quoted in the Stock Exchange Official Daily List on specified dates in 1946, by reference to the mean of the quotations appearing on those dates, or the mean of the quotations on specified dates in 1945, whichever was the higher. With regard to fresh issues of securities after November $8, \mathrm{r} 946$, the value of every security was deemed to be the average of the values of all the securities of that class calculated on a specified basis other than the foregoing, while special provisions are also laid down relating to the conversion of securities, after that date. Any securities not quoted on the London Stock Exchange or not coming within the last foregoing provisions were valued by agreement between the stockholders' representative and the Minister of Fuel and Power, or in default of agreement, by arbitration.

As far as the valuation of securities under the Gas Act, 1948, is concerned, this, too, was based on the Stock Exchange principle. Where securities were quoted in the Stock Exchange Official Daily List on certain dates in 1947, or 1945, their value was to be either the average of the mean of the quotations for that class of security on the dates in 1947 , or the average of the mean of the quotations on the specified dates in 1945, whichever was the higher. Special valuations were made in respect of fresh issues of securities made after December 31, 1945, and in respect of conversions of securities. The value of securities which were not quoted on the Stock Exchange on the specified dates was determined by agreement between the stockholders' representative and the Minister of Fuel and Power, and in default of agreement by arbitration.

Finally, both the Electricity Act, 1947, and the Gas Act, 1948, contain special provisions relating to compensation payable to composite companies and to local authorities. Composite companies are companies which supply another commodity such as water as well as gas and electricity, and which remain in existence even though their gas or electricity undertakings have been expropriated. Under the Electricity Act, I947, the total value of the securities of a composite company was apportioned between the electricity and the other undertakings on the basis of the annual net revenues of the electricity and the other undertakings in the financial years corresponding to the financial years $1944-46$, the compensation payable being the portion so found to be appropriate to the electricity undertaking, together with an arbitrary allowance for severance of $5^{\text {s }}$ per thousand units sold in 1946 . Similar provisions, mutatis mutandis, are contained in the Gas Act, $x 948$.

With regard to local authorities, the liability of an Area Gas Board and the Central Electricity Authority for compensation was limited to the payment of lump

\footnotetext{
is A redeemable mortgage debenture is a security within the meaning of the Gas Act, I9.4, and must be treated as such, see Pearl Assurance Co. Ltd. v. West Midlands Gas Board, [1950] 2 All E. R. 844.
} 
sums in respect of loans and interest thereon as well as payments in respect of existing redemption arrangements when they fall due. Payment was also made to compensate for severance, that is to say, the loss of revenue from electricity departments towards the general expenses of the authority, the sum of five million pounds being divided among local authorities in respect of their electricity undertakings and two and a half million pounds in respect of their gas undertakings. A further amount of compensation was also payable to local authorities in respect of their electricity undertakings for certain capital expenditures incurred after November I9, 1945 .

As far as the satisfaction of compensation is concerned, this took the form of government stock, specially issued by both the Central Electricity Board and the British Gas Control. Both the British Electricity Stock and the British Gas Stock is issued on terms and conditions approved by the Treasury. The annual interest has been determined at 3 per cent.

The amount of stock which was issued to holders of securities valued according to the above principles, was that amount which in the opinion of the Treasury was on specified dates of a value equal to the value of the securities, regard being had to the market value of government securities on certain dates. The same provision applied to both Electricity and Gas Stock, different dates being specified in each case. $^{\text {sc }}$

The provisions of these Acts relating to nationalization and compensation are similar to some of the corresponding provisions contained in the different acts which have previously been discussed. For instance, the physical assets of the electricity and gas undertakings have been transferred under their appropriate Acts to their respective statutory boards, in the same way that physical assets of companies engaged in the coal mining industry and road haulage transport and railway industries were transferred by the Coal Industry Nationalisation Act, 1946, and Transport Act, 1947, to their respective statutory boards. On the other hand, compensation was awarded under the Electricity Act, 1947, and Gas Act, 1948, not in respect of assets as was the case of the industries just cited, but in respect of the securities of the companies operating electricity and gas undertakings, as in the case of the companies engaged in the iron and steel industries which are nationalized by the Iron and Steel Act, 1949. The compensation awarded for local authorities, however, was similar in the cases of the Transport, Electricity, and Gas Acts.

One final point must be mentioned in discussing the statutory provisions relating to compensation for expropriated property, and that relates to negotiability of government stock issued by way of compensation to owners for the loss of their property. This subject may be regarded from two aspects. In the first place, the

5T The nominal value of British Electricity Stock issued up to May 24, 1949, was $£_{445,23,861 \text {; }}$ annual interest thereon amounted to $f_{1} \times 3,369,172.465$ H. C. DEB. 53,70 (5th scr. 1949). Total compensation value of gas securities issued up to Nov. 9, 1949, was $£ 126$ million. 469 H. C. Dev. 129 (5th ser. 1949). 
terms upon which such stock is held must be considered, and, secondly, the restrictions upon its subsequent disposal must be examined.

As far as the first matter is concerned, it is usual for an act of Parliament which has expropriated the securities of a company and which provides for compensation by way of government stock to include provisions to the effect that the substituted stock is to be held on the same rights and trusts and subject to the same powers, privileges, provisions, charges, restraints, and liabilities as those on, or subject to which the former securities were held immediately before the day of conversion. The Port of London Authority Act, $1908,{ }^{5 / 5 z}$ contained provisions to this effect, and this practice has been followed in the recent acts which have expropriated securities.

Provisions such as these are of considerable importance as far as settlements of property are concerned, and give rise to various problems. For instance, in the case of In re Municipal and General Securities Company's Trust Deed,57 a fixed investment trust constituted and regulated by a trust deed held a number of share units which included shares nationalized by the Transport Act, 1947, the Electricity Act, 1947, and the Gas Act, I948. Government stock had already been issued by way of compensation in respect of the shares nationalized by the first two Acts and was intended to be issued in respect of the Gas Act, 1948. The point in issue here was whether the trustees were under any duty or had any power to sell the compensation stocks and if not, whether the Court would authorize such a sale under the Trustee Act, $1925 .{ }^{58}$ It was held that having regard to the provisions of the Acts relating to the terms upon which the substituted stock was to be held, the compensation stocks issued in exchange for the stocks of nationalized undertakings must be held on the same trusts and subject to the same powers and liabilities as the stocks for which they were exchanged, and that, therefore, although an entirely different kind of stocks was now held in place of the original stocks, they must be retained by the trustees and there was no power or duty to sell them. The Court, moreover, could not authorize such a sale under the Trustee Act, $1925 .{ }^{59}$

With regard to the second aspect of negotiability, all government stock which is issued in compensation for expropriated assets whether in reference to securities, physical assets, or any other matter, may be freely negotiated by the holders thereof. In fact, provisions to this effect have been included in the acts which nationalize industries with special reference to persons such as trustees or personal representatives who are empowered to dispose of such stock subject of course to the liabilities of their trusts.

There was, however, an important exception to this freedom of disposal. This

con 8 EDw. 7, c. 68.

[7 [1949] 2 All E. R. 937 (Ch. D.).

88 I5 GEO. 5, C. 19.

5o As to whether government stock issued in lieu of stock comprised in a settlement forms part of capital or income, see In re Sechiari dec'd, [1950] I All E. R. 417, 4I9, distinguished in In re Winder's Will Trusts, [195I] 212 L. T. News 2I, and applied in In re Kleinwort's Settlement Trusts, [195I] 212 L. T. News 22. See also In re Galway's Will Trusts, (I94X) 65 T. L. R. 499. 
was the case of companies to which government stock has been issued as compensation under the Coal Industry Nationalisation Act, 1946. This Act provided that compensation stock, when so issued, must not be sold or otherwise disposed of except by way of return of capital, on a winding up, for the purpose of satisfying the obligations of the company, or for the purpose of raising capital for the development of business; and when disposed of for such purposes, the stock would be free from any such restriction. These restrictions were, however, repealed by the Coal Industry Act, $1949^{.592}$

A review of the measures relating to compensation shows that a variety of methods has been used by the legislature which bear little or no relation to each other. Apart from certain common matters such as the similar treatment of all property belonging to local authorities in the different acts which affect their interests, and the use of the Stock Exchange quotation as the main criterion of the valuation of securities, the methods of compensation differ in regard to each industry. Therefore, in concluding this review of the different statutory provisions relating to compensation for nationalized assets, the words of Lord Porter may be cited:

... I do not find myself assisted by the provisions of other statutes or regulations dealing with the price to be paid for expropriated shares. Each contains its own terms and deals with questions incidental to the transfer of the particular interest taken over by the Government in specified industries. They follow no general principle and have no bearing the one on the other. Nor, when dealing with shares, do I find any useful analogy in the principle on which the value of land compulsorily acquired is to be determined..$^{60}$

\section{III}

These provisions relating to the grant of compensation for the expropriation of assets are of great variety and diversity. Such characteristics, together with the complexity of their nature, might make it seem difficult, if not impossible, to make any general conclusions about them. But this is not so, since from the legal aspect it is possible to draw certain deductions applicable to all of them.

In the first place, the right to compensation which has been granted to disappropriated owners in all of these statutes relating to the nationalization of industries, is a legal right. It is conferred upon them by act of Parliament and can only be taken away from them by passing another act of Parliament for that purpose. This means that an owner can estimate the amount of compensation that he is likely to receive, by examining the terms of the statute as amplified by any regulations made thereunder.

But although the owners have this right to compensation, the grant of the compensation to them is purely arbitrary in the majority of cases in which it is awarded. As the provisions are embodied in an act of Parliament, the owners are precluded from challenging their validity in any court of law although any similar provisions

c9ะ $12,13 \& 14$ GEO. 6, c. 53 .

${ }^{\circ 0}$ In Short v. Treasury Commissioners, [1948] A. C. 534, 544. 
contained in a form of delegated legislation may, broadly speaking, be so contested.

Secondly, there does not appear to be any instance among the provisions reviewed in this essay of a right of appeal to a court of law conferred upon an owner whose assets have been compulsorily acquired by the state, against a decision or determination of a minister in regard to a matter relating to compensation. The most that these provisions allow in the event of an objection being made to a decision of the minister is an appeal to arbitrators especially appointed for the purpose. Such a right of appeal is, however, only given in particular cases, most of those cited in this essay being instances in which the legislature has refrained from including precise terms in an act of Parliament. ${ }^{61}$

Should, however, any board fail to carry out its duty of dispensing the compensation or exceed or abuse the statutory powers conferred upon it, then since all these statutory bodies are subject to the general law, there seems no reason why the appro.o arbitration or has been determined by a referee, an arbitrator or referee may state or be required to state a case for the opinion of the court. ${ }^{62}$ So, in these ways the courts acquire jurisdiction over these provisions relating to compensation.

Finally, these provisions relating to the award of compensation in respect of assets which have been expropriated by the state, though they are transitory in nature, are nevertheless of vital and of long-standing importance to both those persons who have received compensation for their loss and to the boards which are required to issue stock for the purposes of compensation. In the former case, the replacement of securities by government stock has a far-reaching effect inasmuch as although the capital may be replaced the income arising from the substituted stock is inevitably less than the former income by reason of the fixed rate of interest, ${ }^{63}$ while in the latter case the boards are saddled with the responsibility of creating large amounts of stock for the purpose of satisfying the compensation. Thus one might say that both parties are required to bear a loss.

In conclusion, it is hoped that this essay upon the principle of compensation for the expropriation of property will be of some interest to readers abroad. Transitory though the provisions relating to compensation in respect of the recently nationalized industries may he, the principle of compensation for the expropriation of property is an integral part of the English legal and political system, and for that reason, alone, these provisions are worthy of research and consideration.

ox Sec supra pp. 603, 605, 607, 611, 615.

${ }^{2}$ Cases may be stated to the Court of Appeal from tribunals set up under Transport, Electricity, and Gas Acts. As to cases stated by referces under Coal Industry Nationalisation Act, 1946, see sttpra, p. 608, and Studholme v. Minister of Fuel and Power, The Times, June 19, 1951, p. 2, col. 7.

${ }^{\circ 0}$ Interest in every case is determined at 3 per cent. All government stock issued by way of compensation is now quoted below par. There has therefore already been a capital depreciation in the amount of compensation awarded.

It might here be mentioned that the view of the Conservative Party towards the assessment and valuation of compensation is that it should be assessed so as to give compensation for the income of the disappropriated owner and not merely the capital value of his assets. 